\title{
A Marinha e o alinhamento brasileiro aos Estados Unidos, 1935- 1942
}

\section{The Brazilian Navy and the alignment to the United States, 1935- 1942}

Resumo: Neste artigo pretendemos entender o papel da Marinha do Brasil no processo do alinhamento brasileiro aos Estados Unidos na Segunda Guerra Mundial. Considerando a importância dos militares dentro do Estado Novo bem como a divisão da cúpula do regime em setores pró-Aliados e pró-Eixo, a Marinha destaca-se como uma importante instituição posicionada favoravelmente aos Estados Unidos. Desta maneira, é importante apontar a formação de um consenso interno na Marinha favorável ao país, motivada por duas questões: a influência da Missão Naval Americana e o apoio à renovação da esquadra brasileira.

Palavras-chave: Poder Naval Brasil, Aliança Brasil-Estados Unidos, Segunda Guerra Mundial.
Abstract: In this article, we sought to understand the role of Brazilian Navy in the process of Brazilian alignment to the United States in World War II. Considering the importance of the military in the dictatorship of Estado Novo and the division between pro-Allied and pro-Axis in the leadership of the regime, the Brazilian Navy favored a pro-US position. It is important to point out the formation of an internal consensus in the navy in favor to the United States, result of two issues: the influence of the American Naval Mission and the US support to the renewal of the Brazilian war fleet.

Keywords: Naval Power - Brazil, Brazil-United States Alliance, World War II.

\footnotetext{
${ }^{1}$ Doutorando em Ciência Política pela Universidade Federal de São Carlos. Bolsista da Fundação de Amparo à Pesquisa do Estado de São Paulo. E-mail: ludolfjr@hotmail.com
} 


\section{Introdução}

Ao fim da Segunda Guerra Mundial existia um ambiente bastante favorável aos Estados Unidos no Brasil, fruto das intensas relações entre os países durante o conflito global. Da mesma maneira, existia um senso de grande proximidade entre as Forças Armadas do Brasil com suas congêneres estadunidenses, especialmente entre a Marinha do Brasil e a US Navy.

Essa proximidade era tão significativa que, segundo Martins Filho, ${ }^{2}$ chegou a alarmar o Departamento de Estado estadunidense quanto ao risco do surgimento de uma potência militar regional que atrapalhasse seus planos para a América Latina. Alves ${ }^{3}$ lembra que o americanismo foi uma característica fundamental do poder naval brasileiro nos primeiros anos da Guerra Fria.

Essas relações amistosas entre as duas forças navais têm origem algumas décadas antes, especialmente com a chegada da Missão Naval Americana ao Brasil, em 1922. Elas ganharam uma nova dimensão com o alinhamento brasileiro aos Estados Unidos durante a Segunda Guerra Mundial, quando combateram lado a lado as forças do Eixo no Atlântico Sul.

A entrada do Brasil neste conflito, como se sabe, foi marcada por intensas negociações com os blocos de poder que se formavam, especialmente com a Alemanha e os Estados Unidos. O governo de Getúlio Vargas buscou conseguir o máximo de vantagens possíveis ao Brasil, tomando atitudes dúbias para conseguir as duas grandes prioridades da política externa do Estado Novo: a instalação de uma grande indústria siderúrgica e armamentos novos para as Forças Armadas. ${ }^{4}$

Como apontam Cervo e Bueno, ${ }^{5}$ a ambiguidade do governo Vargas em relação à disputa Eixo-Aliados refletia também uma tensão existente na cúpula do Estado Novo. O ministro das Relações Exteriores, Oswaldo Aranha, era apontado como uma das figuras mais favoráveis aos Estados Unidos. De outro lado, Filinto Müller, Chefe de Polícia de Vargas, mantinha

\footnotetext{
2 MARTINS FILHO, João Roberto. As políticas militares dos EUA para a América Latina (1947-1989). Teoria \& Pesquisa. São Carlos, n. 46, 2005. P. 103.

${ }^{3}$ Ver ALVES, Vágner Camilo. Ilusão desfeita: a "aliança especial" Brasil-Estados Unidos e o poder naval brasileiro durante e após a Segunda Guerra Mundial. Revista Brasileira de Política Internacional. Brasília, v. 48, n. 1, 2005.

${ }^{4}$ Id. O Brasil e a Segunda Guerra Mundial. Rio de Janeiro/São Paulo: PUC-Rio/Loyola, 2002. P. 103.

${ }^{5}$ CERVO, Amado Luiz e BUENO, Clodoaldo. História da política exterior do Brasil. Brasília: Editora Universidade de Brasília, 2008. P. 250.
} 
contato constante com a Embaixada do Reich, enquanto as principais lideranças do Exército, os generais Dutra e Goés Monteiro, eram considerados germanófilos. ${ }^{6}$

A divisão na cúpula do regime Vargas implica na existência de uma dinâmica política em relação ao posicionamento brasileiro, que envolvia autoridades, instituições governamentais e o desenvolvimento do cenário internacional. Este processo não passava despercebido pelas potências que disputavam o posicionamento brasileiro. Oliveira ${ }^{7}$ aponta que as autoridades estadunidenses, ao observarem o jogo de poder na cúpula militar e civil do governo Vargas, buscavam se antecipar às iniciativas brasileiras. Certamente as lideranças diplomáticas do Eixo faziam o mesmo.

Neste quadro, a opinião dos militares tinha um peso considerável, uma vez que eram uma das principais bases de sustentação do regime Vargas. Como lembra Carvalho, ${ }^{8}$ o presidente aliou-se com as Forças Armadas, apoiando a transformação delas num ator político de primeira ordem, para ocupar o espaço aberto pela crise oligárquica e garantir sua sustentação no poder enquanto realizava sua modernização conservadora no Brasil. Para isso, apoiou a criação de um consenso interno nas Forças Armadas eliminando tendências políticas conflitantes. Em troca do apoio castrense para sua sustentação no poder, Vargas ofereceu aos militares o compromisso de modernizá-los com equipamento bélico novo. ${ }^{9}$ A necessidade de armamentos e o peso político das Forças Armadas tornaram os militares agentes importantes na política externa do Estado Novo.

Considerando o quadro exposto, nosso objetivo é entender qual era a posição da Marinha em relação ao alinhamento brasileiro na Segunda Guerra Mundial. Para isso buscamos elucidar quais eram as divisões internas na força naval e como se expressavam em relação ao posicionamento brasileiro, bem como verificar a construção de um consenso interno na Marinha.

\section{A Marinha na década de $\mathbf{1 9 3 0}$}

No início da década de 1930, a Marinha não se encontrava nas melhores condições. Com uma esquadra dolorosamente obsoleta e em

\footnotetext{
6 McCANN, Frank D. Aliança Brasil-Estados Unidos. Rio de Janeiro: Biblioteca do Exército, 1995. P. 37; BANDEIRA, Luiz Alberto Moniz. Presença dos Estados Unidos no Brasil. Rio de Janeiro: Civilização Brasileira, 2007. P. 391.

${ }^{7}$ OLIVEIRA, Dennison de. Aliança Brasil-EUA. Curitiba: Juruá, 2015.

${ }^{8}$ CARVAlHO, José Murilo. Forças Armadas e Política no Brasil. Rio de Janeiro: Jorge Zahar Ed., 2006. P. 110; 116-117.

${ }^{9}$ McCANN, 1995, op. cit., p. 44.
} 
péssimo estado, vivia em esperança de dias melhores. O núcleo da frota era formado por navios construídos antes da Primeira Guerra Mundial: os encouraçados dreadnoughts classe Minas Geraes,${ }^{10}$ os cruzadores classe Bahia, os contratorpedeiros classe Pará e os submarinos classe Foca, além do contratorpedeiro Maranhão, foram construídos entre 1906 e 1914; ainda eram parte da frota o cruzador Barroso e o encouraçado pré-dreadnought Floriano, então verdadeiras relíquias do século XIX, além do submarino Humaytá, incorporado em 1929 e única unidade moderna. ${ }^{11}$

Quase todas estas embarcações estavam em péssimas condições. Um bom exemplo disso pode ser observado na situação dos contratorpedeiros da classe Pará. Enquanto o próprio ministro da Marinha ${ }^{12}$ reconhecia que os contratorpedeiros mal podiam navegar distantes da costa devido ao seu estado, o Estado Maior da Armada sugeriu aos comandantes destes navios que navegassem apenas em velocidades "moderadas" tendo-se em conta a avançada idade deles, bem como para evitarem fazer disparos com canhões maiores sob riscos estruturais às embarcações. ${ }^{13}$ A situação tornava-se ainda mais alarmante quando considerava-se que o poder naval da tradicional rival, a Argentina, superava em muito o brasileiro. ${ }^{14}$ Estas situações apontavam para a necessidade imediata de renovação material.

Além das dificuldades materiais, a Marinha encontrava-se politicamente dividida. Desde a Proclamação da República e especialmente após a Revolta da Armada, em 1893-1894, a Marinha perdia força e prestígio político. ${ }^{15}$ Foi uma instituição chave na política externa do Barão de Rio Branco, quando foi modernizada com uma poderosa esquadra, porém logo caiu em desconfiança novamente por ocasião da Revolta da Chibata,

\footnotetext{
${ }^{10}$ Os nomes dos navios variaram de acordo com as reformas ortográficas ocorridas. Para este artigo, decidimos manter a grafia original.

${ }^{11}$ MARTINS, Hélio Leôncio et al. A Marinha Brasileira no período entre as guerras (19181942). In: HISTÓRIA Naval Brasileira. Rio de Janeiro: Serviço de Documentação Geral da Marinha, 1985. P. 100-105.

12 MINISTÉRIO DA MARINHA. Relatório Apresentado ao Exmo. Chefe do Governo Provisório. Rio de Janeiro: Imprensa Naval, 1932. P. 18.

13 HILTON, Stanley E. O Brasil e as Grandes Potências 1930-1939. Rio de Janeiro: Civilização Brasileira, 1977a. P. 185-186.

${ }^{14}$ Nas primeiras décadas do século, a Argentina buscou manter uma marinha cujo poder fosse igual ou superior aos seus maiores rivais: Brasil e Chile, que eram, juntamente com a Argentina, as maiores potências navais da América Latina. Durante a década de 1930, com a aquisição de novas unidades, o país quase conseguiu atingir essa meta. SCHEINA, Robert L. Latin America, a naval history 1810-1987. Annapolis: Naval Institute Press, 1988. P. 146.

${ }^{15}$ Ver VIDIGAL, Armando Amorim Ferreira. A evolução do pensamento estratégico naval brasileiro. Rio de Janeiro: Biblioteca do Exército, 1985. P. 50-54.
} 
em 1910. ${ }^{16}$ Nos últimos anos da Primeira República, manteve-se quase totalmente legalista: durante as revoltas tenentistas houve poucos núcleos rebeldes na força naval, cujo principal manifestou-se na insurreição do encouraçado São Paulo em 1924. Durante a Revolução de 1930, a Marinha majoritariamente combateu as forças de Vargas. ${ }^{17}$

Apesar do apoio ao governo Washington Luís, a Marinha mantevese governista nas rebeliões do início da década de 1930. Em 1932, ainda que houvesse simpatia de grande número de oficiais com a revolta paulista, a Marinha se empenhou em sufocar a Revolução Constitucionalista e praticamente ninguém de seu pessoal se envolveu com a Intentona Comunista de $1935 .{ }^{18}$

O legalismo naval, entretanto, não significou lealdade automática à Vargas. Muitos oficiais da Marinha estavam ligados ao regime anterior; havia elementos tenentistas e uma profunda divisão entre oficiais e praças. Este quadro de divisão interna e as péssimas condições materiais da esquadra criavam uma situação de instabilidade para o governo Vargas. Observadores estrangeiros já percebiam isso: enquanto um estadunidense afirmou, no início da década, que o governo precisaria alocar recursos para a renovação da Marinha, correndo risco de que oficiais "com mentalidade política" poderiam se colocar em "pé-de-guerra contra o governo"; um observador britânico avisava que era perigoso ficar testando a paciência da Marinha com promessas não cumpridas. ${ }^{19}$

As necessidades materiais da Marinha e o desejo de Vargas em conseguir o apoio naval ao seu regime levaram à aprovação de um programa de renovação da esquadra em 1932, que estabelecia a necessidade de aquisição de cruzadores, contratorpedeiros e submarinos. ${ }^{20}$ Esse programa, revisado durante os anos seguintes, norteou toda a modernização da esquadra na década de $1930 .^{21}$ Além da aprovação do programa naval, Vargas também autorizou em 1932 a criação do Fundo Naval, destinado a

\footnotetext{
${ }^{16}$ Ibid., p. 59-62.

${ }^{17}$ Ver MARTINS et al, op. cit., p. 121-33.

${ }^{18}$ Ibid., p. 136-141.

${ }^{19}$ HILTON, 1977a, op. cit., p. 189.

${ }^{20}$ MINISTÉRIO DA MARINHA, 1932, op. cit., p. 19.

${ }^{21}$ Para ver as alterações, ver MINISTÉRIO DA MARINHA. Relatório Apresentado ao Exmo. Sr. Presidente da República dos Estados Unidos do Brasil. Rio de Janeiro: Imprensa Naval, 1934. P. 14; Id., Relatório dos Serviços do Ministério da Marinha correspondente aos anos de 1937 - 1938 - 1939. Rio de Janeiro: Imprensa Naval, 1940. P. 19.
} 
garantir uma fonte de renda para a Marinha que não estava ligada aos repasses tradicionais do governo. ${ }^{22}$

A alocação de recursos para a modernização naval deu ao presidente certa estabilidade com relação aos seus almirantes, porém não foi suficiente para garantir pleno apoio da Marinha ao regime nos anos seguintes, como observaria um memorando do Departamento de Estado posteriormente. ${ }^{23}$ As relações entre a oficialidade e o sistema político eram mais complexas. Vargas teria que agir em outras frentes. Precisava lidar com as divisões internas - algo que ele sabia manipular muito bem para seus interesses políticos $^{24}$ - mas em última instância precisaria construir um consenso favorável ao seu regime. E a crescente radicalização da década de 1930 apontava grandes dificuldades para que isso ocorresse.

As divisões entre as opções políticas não eram as únicas existentes na Marinha. A oficialidade também dividia-se quanto aos modelos de organização naval e preferência de fornecedor de navios de guerra. Tradicionalmente existia uma grande influência britânica, cuja marinha era a mais poderosa da época e modelo para as congêneres latino-americanas. No caso brasileiro, a influência britânica sobre o material bélico naval era muito clara: todos os navios mais importantes, citados anteriormente, foram construídos na Grã-Bretanha, com exceção dos submarinos (de origem italiana) e do Floriano (fabricado na França). ${ }^{25}$

Rivalizando com os britânicos, havia uma crescente influência dos Estados Unidos, que ao final da década de 1930 já substituiriam os europeus na posição de principal influência sobre a força naval. Boa parte da razão desta mudança é devido à ação da Missão Naval Americana, instalada no Brasil em 1922.

\section{A Missão Naval Americana}

Quando o encouraçado Minas Geraes aportou no Rio de Janeiro, em 1910, foi recebido por uma enorme festividade, exaltado pela imprensa, autoridades governamentais e pela população num fervor patriótico. A despeito do entusiasmo geral provocado pela chegada do navio e da nova frota nos meses seguintes, a Marinha acabou encontrando-se num paradoxo. Ao mesmo tempo em que tinha uma esquadra poderosa, equipada com

\footnotetext{
22 Id., 1932, p. 81-83.

${ }^{23}$ US DEPARTMENT OF STATE. Research Memorandum: The Armed Forces and Police in Brazil. 1969. 115 p. p. 65.

${ }^{24}$ CARVALHO, op. cit., p. 105.

25 VIDIGAL, op. cit., p. 54, 59-60, 64, 66, 74.
} 
tecnologia de ponta, seus oficiais e marinheiros tinham baixíssima capacidade técnica. Neste sentido, Londres já previa que assim que os técnicos britânicos retornassem ao seu país, os brasileiros não conseguiriam operar adequadamente os complexos equipamentos dos novos navios e que as máquinas ficariam rapidamente em péssimo estado. ${ }^{26}$

A necessidade de aprimorar a capacitação técnica dos oficiais entrou na pauta das lideranças navais. Assim como no caso do Exército, que passava por situação semelhante quanto ao seu pessoal, decidiu-se apelar para o exterior. Ainda em 1910 o ministro da Marinha propôs a vinda de instrutores britânicos para treinamento de oficiais, mas a medida foi recusada por Rio Branco. ${ }^{27}$ Foi apenas com a criação da Escola Naval de Guerra, em 1914, que contratou-se um instrutor estadunidense, o capitão-defragata Philips William. ${ }^{28}$ Esta ação marcou o início nas relações militares Brasil-Estados Unidos. ${ }^{29}$

Com a entrada do Brasil na Primeira Guerra Mundial, em 1917, o país recebeu oficiais britânicos e estadunidenses para auxiliar a preparação naval para o confronto. Ainda assim, o Brasil teve enormes dificuldades organizar a sua Divisão Naval em Operações de Guerra, que somente chegou ao destino, Gibraltar, alguns dias antes do armistício. ${ }^{30} \mathrm{~A}$ participação no conflito expôs as péssimas condições e o estado obsoleto dos navios da Marinha. A necessidade de se modernizar, tanto material como institucionalmente, tornou-se clara.

A Marinha então dividiu-se. Alguns oficiais tinham preferência pelos britânicos, tradicionais fornecedores e modelo para a força naval brasileira, enquanto outros viam com bons olhos os Estados Unidos, que deram grande apoio ao Brasil durante o conflito mundial. A questão era apimentada porque também envolvia a escolha do país que modernizaria os encouraçados Minas Geraes. Ao final de 1918 o grupo pró-Estados Unidos prevaleceu e os encouraçados foram enviados para Nova Iorque, onde foram modernizados em 1919-1920. ${ }^{31}$

Os reparos nos encouraçados nos Estados Unidos bem como o envio de oficiais da Marinha para estágio naquele país tiveram consequências importantes dentro da força naval. Ao retornarem ao Brasil, os oficiais que

\footnotetext{
${ }^{26}$ Ver MARTINS FILHO, João Roberto. A Marinha Brasileira na Era dos Encouraçados, 1895-1910. Rio de Janeiro: FGV, 2010. P. 167-195.

${ }^{27}$ Ibid., p. 179.

${ }^{28}$ MARTINS et al., op. cit., p. 214.

${ }^{29}$ DAVIS, Sonny B. A brotherhood of arms: Brazil-United States military relations, 1945-1977. Niwot: University of Colorado, 1996.

${ }^{30}$ SCHEINA, op. cit., p. 92-97.

${ }^{31}$ SCHEINA, op. cit., p. 96-97.
} 
fizeram estágio deram início à um movimento clamando por mudanças na Marinha, de forma a atualizá-la. Ficaram conhecidos como "arquiduques" e constituíam um relevante núcleo pró-Estados Unidos. Ainda que sua influência era relativamente reduzida por não estarem posicionados nas principais esferas hierárquicas, promoveram um importante ímpeto de modernização que se construía na Marinha. ${ }^{32}$

Este ímpeto de modernização também estava presente no Exército. Em 1920, esta força contratou a Missão Francesa. A ideia de contratar uma missão para a Marinha logo chegou aos centros de decisão naval. O então presidente, Epitácio Pessoa, era favorável à essa medida, ${ }^{33}$ assim como o ministro da Marinha, Veiga Miranda, um dos poucos civis a ocuparem esse posto na história republicana. ${ }^{34} \mathrm{~A}$ escolha do fornecedor da missão recaiu nos Estados Unidos. Para essa decisão foram decisivos a modernização dos encouraçados nesse país, a existência de instrutores estadunidenses no Brasil e a opinião favorável dos arquiduques e de outros oficiais.

Para Washington tal ideia era muito interessante, principalmente em termos pragmáticos. Em primeiro lugar, uma missão naval é capaz de influenciar decisivamente os hábitos de aquisição da marinha receptora. $\mathrm{O}$ país fornecedor também conseguia manter presença contínua no receptor, além de ser uma boa maneira para conseguir ser favorecido em termos econômicos e militares. ${ }^{35}$ Isso é visível num memorando da US Navy, de 1945, que dizia que, dentre outros fins, a Missão Naval dos Estados Unidos no Brasil devia assegurar a "predominância dos Estados Unidos nos assuntos brasileiros e no continente americano" e "... introduzir o emprego material dos Estados Unidos na Marinha do Brasil para promover o comércio americano...". ${ }^{36}$

A missão chegou ao Brasil nos últimos dias de 1922. Inicialmente, foi recebida com desconfiança por parte da oficialidade, especialmente pelos mais graduados na hierarquia. Segundo um oficial contemporâneo, Américo Vieira Mello, uma alta autoridade naval chegou a afirmar que a chegada da missão era "um desprestígio para os almirantes". As tensões prosseguiram com o início das atividades da Missão Naval Americana, inclusive ocorreram desentendimentos entre o ministro da Marinha, Alexandrino Alencar, com membros da missão. Sintomático do mal estar

\footnotetext{
32 VIDIGAL, op. cit., p. 75.

${ }^{33}$ MELLO, Américo Vieira de. Memórias: Visão Histórica da Marinha Brasileira, 1895-

1945. Belo Horizonte: O Escriba, 1994. P. 99.

${ }^{34}$ MARTINS et al, op. cit., 214.

${ }^{35}$ SCHEINA, op. cit., p. 127-128.

${ }^{36}$ McCANN, 1995, op. cit., p. 357-358.
} 
era a reclamação do chefe da missão, o contra-almirante Carl Theodore Vogelgesang, de que não o consultavam sobre questões que ele deveria ajudar. $^{37}$

Apesar dos estranhamentos iniciais, a missão continuou seus trabalhos. Ela acabou influenciando a organização da Marinha, especialmente na Escola de Guerra Naval, nos exercícios navais e na rotina dos vasos de guerra, além de pequenas mudanças na organização burocrática da força. ${ }^{38} \mathrm{~A}$ missão também buscou influenciar a aquisição de armamentos, entretanto sem grandes resultados. Houve a sugestão para a compra de um navio-tanque para ser usado como navio aeródromo, ${ }^{39}$ além de, em 1924, recomendar que o Brasil levasse a cabo um extensivo programa de renovação naval focado em encouraçados e cruzadores. ${ }^{40} \mathrm{~A}$ construção destes navios, que ocorreria nos Estados Unidos e teria custos altíssimos, acabou criando atritos com o Departamento de Estado, que ficou alarmado com a possibilidade de que este plano, se fosse colocado em prática, atrapalharia os planos de Washington na região. ${ }^{41}$ É interessante notar que desencontros semelhantes na política militar-diplomática dos Estados Unidos para o Brasil ocorreriam posteriormente.

A Missão Naval Americana continuou em atividade até 1930. Neste ano, em virtude do apoio estadunidense ao governo de Washington Luís e da recusa em vender armamento aos rebeldes, o Governo Provisório de Vargas decidiu não renovar o contrato da missão, que encerrou suas atividades ainda em novembro daquele ano. ${ }^{42}$ Entretanto, o afastamento da Marinha em relação aos Estados Unidos durou pouco. Em 1931 o Brasil buscou, sem sucesso, adquirir cruzadores naquele país. A razão principal era a vigência do Tratado Naval de Washington de 1922, que limitava a tonelagem total das maiores potências navais do globo e proibia a venda deste tipo de navio. ${ }^{43}$ Em 1933 chegaram dois oficiais estadunidenses para servirem de instrutores na Escola Naval; com a aprovação dos recursos para a modernização da Marinha, o ministro Protógenes Guimarães recontratou a Missão Naval Americana em 1935. ${ }^{44}$

\footnotetext{
${ }^{37}$ MELLO, op. cit., p. 100-101.

${ }^{38}$ MARTINS et al, op. cit., 214.

${ }^{39}$ MINISTÉRIO DA MARINHA, 1932, op. cit., p. 55.

${ }^{40}$ SCHEINA, op. cit., p. 135.

${ }^{41}$ Ibid., p. 135-136.

${ }^{42}$ CERVO E BUENO, op. cit., p. 233.

${ }^{43}$ SCHEINA, op. cit., p. 137.

44 MINISTÉRIO DA MARINHA. Relatório Apresentado ao Exmo. Sr. Presidente da República dos Estados Unidos do Brasil. Rio de Janeiro: Imprensa Naval, 1935. P. 9-10.
} 
Diante do apoio estadunidense à Marinha, principalmente através da missão naval, grande parte da oficialidade acabaria assumindo uma postura pró-Estados Unidos durante a polarização e crise internacional no decorrer da década de 1930. Em termos ideológicos, um novo grupo surgiu durante esse período, tornando-se uma força bastante expressiva dentro da Marinha ao final da década e que estava mais alinhada com o campo do fascismo. Eram os integralistas.

\section{O integralismo na Marinha}

A Ação Integralista Brasileira (AIB) foi fundada em 1932 por Plínio Salgado, que buscou construir um movimento conservador e nacionalista com influências do movimento fascista europeu. ${ }^{45}$ Esse movimento acabou ganhando muitos adeptos nas Forças Armadas, especialmente na Marinha.

Como lembra Carvalho, ${ }^{46}$ a Marinha era considerada, desde os tempos do Império, como uma arma muito mais aristocrática e conservadora do que o Exército. Era a única instituição militar a atrair os filhos das classes altas para suas fileiras, onde existia um verdadeiro fosso social entre as origens de oficiais e praças. Além disso, as características organizacionais da força naval, seu relativo isolamento e treinamento mais profissional contribuíam para que a Marinha fosse menos hostil às elites políticas e econômicas, especialmente durante a Primeira República.

A influência da AIB na Marinha cresceu significativamente após o episódio da Intentona Comunista, muito devido ao profundo anticomunismo que marcava o pensamento político integralista. Neste sentido, as autoridades navais parecem ter até estimulado o integralismo em suas fileiras como forma de combater o comunismo. ${ }^{47}$

Plínio Salgado declararia em 1946 que 80\% do pessoal da Marinha era integralista. Essa estimativa era claramente exagerada, mas de qualquer modo a influência da AIB era muito visível. Testemunhas afirmavam que centenas de marinheiros costumavam participar dos comícios integralistas. A embaixada estadunidense afirmou em 1937 que metade da oficialidade naval era integralista. ${ }^{48}$ Décadas depois, o almirante Harold Hasselman disse

\footnotetext{
45 TRINDADE, Hélgio. Integralismo. Rio de Janeiro: DIFEL, 1979. P. 244-245.

${ }^{46}$ CARVALHO, op. cit., 52.

${ }^{47}$ MARTINS et al, op. cit., p. 141.

${ }^{48}$ HILTON, Stanley E. O Brasil e a Crise Internacional. Rio de Janeiro: Civilização Brasileira, 1977b. p. 38.
} 
que a maioria da força naval, se não integralista, era simpatizante do movimento. ${ }^{49}$

Além desses relatos, os dados relativos à organização do partido mostram a proximidade do partido com parte significativa da oficialidade naval. A Câmara dos Quarenta, conselho supremo da AIB, incluía dois almirantes. ${ }^{50}$ Chegou a existir na estrutura integralista a chamada Província do Mar, criada especificamente para acomodar o pessoal naval e que tinha células em quase todas guarnições, funcionando aberta e livremente. ${ }^{51}$

Diante da polarização cada vez mais aguda no cenário internacional, os integralistas, em geral, tomavam posição pró-Eixo. Conforme demonstrado por Trindade, ${ }^{52}$ a maioria dos integralistas era simpática ao fascismo europeu, especialmente em relação ao italiano. De fato, a Itália e a AIB mantiveram contatos próximos, fortes o suficiente para que Roma concedesse, em janeiro de 1937, uma subvenção mensal de 50 mil liras ao partido. ${ }^{53}$ Apesar do apoio aos integralistas, a Itália mantinha também relações próximas com o governo Vargas, a despeito das trocas comerciais com esse país serem pouco relevantes para o quadro comercial geral brasileiro. ${ }^{54}$

Existiam setores mais radicais dentro da AIB, que defendiam uma maior aproximação com os totalitarismos europeus, especialmente ao regime nazista. Gustavo Barroso era um exemplo dessa posição. Defendendo que o integralismo poderia se beneficiar do hitlerismo, apoiava uma aliança aberta com os fascismos europeus. ${ }^{55}$ Apesar da posição de radicais como Barroso, a Alemanha evitou maiores contatos com a AIB, pois considerava que o nacionalismo integralista confrontava os interesses culturais alemães no Brasil, especialmente em relação à nacionalização das comunidades teuto-brasileiras. Da mesma maneira, Salgado desconfiava da "idolatria de um homem" e da "falta de base cristã" do nazismo, bem como da propaganda "puramente materialista" do Lebensraum. Por fim, também rejeitava e condenava as teorias raciais alemãs. ${ }^{56}$

\section{Comércio exterior e armamentos}

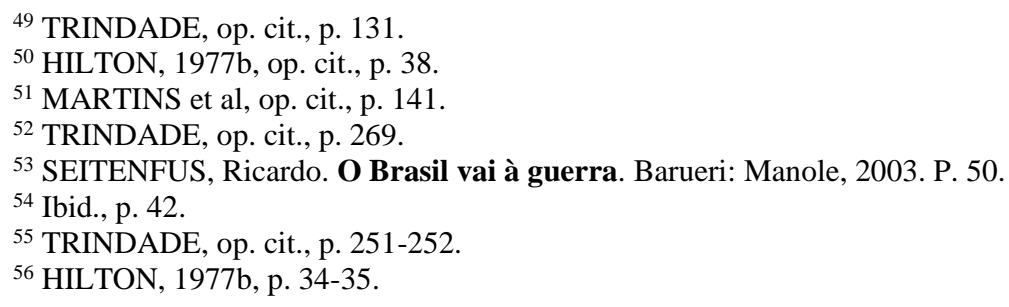


Em 1935, mesmo ano que a Missão Naval Americana retornava ao Brasil, o país assinou acordos com a Alemanha sobre a premissa do comércio de compensação e com os Estados Unidos em termos mais liberais. ${ }^{57}$ Esses acordos marcaram o começo de uma disputa de influência sobre o Brasil que só terminaria por ocasião do alinhamento do Brasil aos Estados Unidos já durante a Segunda Guerra Mundial.

Um ponto essencial dentro da disputa comercial entre a Alemanha e os Estados Unidos era a questão do fornecimento de armamentos ao Brasil. Apesar da Política de Boa Vizinhança estadunidense, a aquisição de armas naquele país não apresentava grandes vantagens aos brasileiros, pois deveria ser realizada pelos meios tradicionais das regras do comércio exterior, através do pagamento com as escassas divisas que o Brasil possuía. Além disso, Washington ainda estava em fase inicial de seu processo de rearmamento e apresentava sérios entraves legislativos internos para o fornecimento de material bélico a países estrangeiros. ${ }^{58}$

De outro lado, o comércio de compensação apresentava a óbvia vantagem aos brasileiros de pagamento com produtos primários. A Marinha logo se interessou pela possibilidade de adquirir navios de guerra desta forma e a partir de setembro 1934 passou a buscar acordos bilaterais dessa natureza. ${ }^{59}$ A Itália rapidamente se interessou pelo projeto. O país era um tradicional fornecedor de submarinos para o Brasil, que desejava tanto este tipo de navio como possivelmente contratorpedeiros - já que a Marinha, então, não fazia questão de que estes navios fossem adquiridos no outro tradicional país vendedor, a Grã-Bretanha. ${ }^{60}$

Tanto Alemanha como Estados Unidos também se interessaram pelo projeto naval brasileiro. Em 1936 as autoridades alemãs prometeram ao Brasil fornecer qualquer quantidade de material bélico, terrestre, aéreo e naval. ${ }^{61}$ Contratos foram realizados para a produção, em solo brasileiro, de vinte aviões de treinamento da alemã Focke-Wulf para a aviação naval, ${ }^{62}$ material da Krupp foi adquirido para a construção do novo arsenal da Marinha na Ilha das Cobras $^{63}$; também houve uma proposta para a

\footnotetext{
${ }^{57}$ ALVES, 2002, op. cit., p. 57.

${ }^{58}$ Ibid., op. cit., p. 79.

59 McCANN, Frank. Soldados da Pátria. São Paulo/Rio de Janeiro: Companhia das Letras/Biblioteca do Exército, 2009. P. 459.

${ }^{60}$ HILTON, 1977a, op. cit., p. 190.

${ }^{61}$ Id., 1977b, op. cit., p. 73.

62 MINISTÉRIO DA MARINHA. Relatório Apresentado ao Exmo. Sr. Presidente da República dos Estados Unidos do Brasil. Rio de Janeiro: Imprensa Naval, 1937.p. 46.

63 BANDEIRA, Luiz Alberto Moniz. Presença dos Estados Unidos no Brasil. Rio de Janeiro: Civilização Brasileira, 2007. p. 377.
} 
instalação de uma fábrica de pólvora para uso naval. ${ }^{64}$ Entretanto, os almirantes brasileiros não pareciam muito receptivos pelos vasos de guerra alemães. O ministro da Fazenda, Artur de Souza Costa, que liderava as negociações com Berlim, disse que nem ele, nem os líderes militares, se interessavam pelos navios germânicos, mas sim pelos canhões. ${ }^{65}$

É interessante notar as diferenças entre a Marinha e o Exército em relação aos armamentos alemães. O Exército Brasileiro era um tradicional consumidor de armas alemãs. A Krupp fornecia canhões ao Brasil desde os tempos do Império; fuzis Mauser, adquiridos ainda na primeira década do século XX, continuavam em uso em meados da década de $1930 .{ }^{66}$ Considerando isso, parecia lógico voltar a obter equipamentos e armas na Alemanha. ${ }^{67}$ Além da tradição, cabe lembrar que as altas lideranças militares demonstravam ter preferência pelos armamentos alemães. Existia a ideia em alguns generais - entre eles, Góes Monteiro - de que as armas de fabricação alemã eram melhores que as estadunidenses. Eles também acreditavam que a Alemanha era a melhor fonte de suprimento de equipamento bélico, uma vez que os Estados Unidos não estavam capacitados para suprir às suas próprias necessidades. ${ }^{68}$

De qualquer maneira, se os navios de guerra alemães não interessavam à Marinha, os estadunidenses interessavam. Como vimos, o Brasil já tinha tentado adquirir cruzadores nos Estados Unidos em 1931. Três anos depois, Vargas, alarmado com os acontecimentos na Guerra do Chaco (1932-1935) - no qual aconteceram incidentes com o Brasil ${ }^{69}$ - pediu para que seu embaixador recém-nomeado nos Estados Unidos, Oswaldo Aranha, consultasse aquele país sobre as possibilidades do Brasil adquirir alguns cruzadores, submarinos e canhoneiras para a defesa fluvial. O presidente Franklin Roosevelt, por sua vez, pediu que Vargas nada fizesse em relação à frota antes de consulta-lo, pois decidira que faria de tudo para

${ }^{64}$ MINISTÉRIO DA MARINHA. Relatório dos Serviços do Ministério da Marinha em 1941. Rio de Janeiro: Imprensa Naval, 1942. P. 45. Entretanto, o ministro da Marinha informou que o início da guerra pôs fim aos esforços, apesar de se ter acertado quase tudo. Ibid., p. 47.

${ }^{65}$ HILTON, 1977a, op. cit., p. 200.

${ }^{66}$ McCANN, 2009, op. cit., p. 43; 265.

${ }^{67}$ Ibid., op. cit. 457.

${ }^{68}$ BANDEIRA, op. cit., p. 386. A ideia de que o armamento alemão era melhor pode ser entendida quando observados armamentos oferecidos ao Brasil: enquanto os canhões germânicos eram novíssimos - eram do mesmo tipo que as tropas alemãs usariam durante a guerra - o material estadunidense era, em geral, de segunda mão. OLIVEIRA, op. cit., p. 47.

${ }^{69}$ HILTON, 1977b, op. cit., p. 67. 
que as unidades desejadas pelo Brasil fossem construídas nos Estados Unidos, em condições melhores e mais vantajosas. ${ }^{70}$

Roosevelt era um famoso entusiasta do poder naval. Bastante influenciado pelas ideias do famoso teórico naval Alfred Thayer Mahan, escreveu trabalhos sobre história naval e era aficionado por encouraçados, tendo exercido funções administrativas na US Navy antes de tornar-se presidente. Durante seu governo, buscou incentivar a construção naval estadunidense através do National Industrial Recovery Act, que tinha estreitas relações com o New Deal. ${ }^{71}$ Neste sentido, para Roosevelt a questão da construção dos navios brasileiros era importante, até mesmo para servir de estímulo para a recuperação econômica dos estaleiros estadunidenses.

Entretanto Roosevelt estava de mãos atadas. Apesar de fazer promessas aos brasileiros, não estava autorizado a fazer vendas de vasos de guerra por uma série de entraves legislativos e acordos internacionais de limitação de armamentos navais. Isso ficou claro aos brasileiros quando tentaram adquirir cruzadores e outros navios nos Estados Unidos em 1936, novamente em vão. ${ }^{72}$

Sem possibilidade de conseguir os navios nos Estados Unidos, a Marinha passou a considerar construí-los no Brasil. Ao menos desde 1932 as lideranças navais brasileiras já pensavam na possibilidade de voltarem a construir vasos de guerra no país, ainda que considerassem a falta da indústria siderúrgica nacional como um obstáculo a isso. ${ }^{73}$ Com a construção do Arsenal da Ilha de Cobras sendo finalizada, em 1934 decidiuse pela construção de três contratorpedeiros naquele lugar. ${ }^{74}$ Os Estados Unidos veriam nessa empreitada uma boa possibilidade de fornecer “indiretamente" os armamentos desejados pela Marinha, através do auxílio à construção naval no Brasil e apoiaram esse empreendimento inclusive durante a Segunda Guerra Mundial. ${ }^{75}$

Quando o Arsenal da Ilha de Cobras ficou praticamente pronto, a Marinha iniciou a construção, em 1936, de um pequeno monitor fluvial, o Parnahyba. Essa era a primeira empreitada do tipo no Brasil em mais de trinta anos e seria seguida pela construção de outro monitor e vários navios-

\footnotetext{
${ }^{70}$ McCANN, 2009, op. cit., p. 442-443.

${ }^{71}$ McBRIDE, William M. Technological change and the United States Navy, 1865-1945.

Baltimore, The Johns Hopkins University Press, 2000. P. 164-167.

72 SCHEINA, op. cit., p. 137.

73 MINISTÉRIO DA MARINHA, 1932, op. cit., p. 86-87.

${ }^{74}$ MINISTÉRIO DA MARINHA, 1934, op. cit., p. 14.

75 Ver WALDMANN JÚNIOR, Ludolf. A construção naval durante a Segunda Guerra Mundial. Rio de Janeiro, Navigator, v.10 nº 20, 2014.
} 
mineiros da classe Carioca ${ }^{76}$ Diante do sucesso que os brasileiros tiveram em retomar a construção naval, Washington decidiu apoiar a empreitada.

Através da Missão Naval Americana, os Estados Unidos cederam, a preços simbólicos, os planos de construção dos contratorpedeiros classe Mahan. ${ }^{77}$ Os estadunidenses ainda se prontificaram em dar toda assistência técnica para a construção, inclusive na formação dos operários. ${ }^{78}$ Desta maneira, em 1937, bateu-se a quilha dos três contratorpedeiros cuja construção ocorreria no Brasil, da classe Marcílio Dias.$^{79}$ Grande parte do material necessário para a fabricação destes navios foi adquirida nos Estados Unidos. ${ }^{80}$ Com isso, Washington conseguia fornecer, ainda que indiretamente, navios de guerra ao Brasil, ultrapassando os entraves legais que impediam a venda de armamentos ao exterior.

Embora a construção de novos navios em solo nacional fosse importante, as necessidades navais brasileiras exigiam embarcações em número e complexidade superior à sua então capacidade de produção. Aproveitando-se das negociações com a Itália com base no comércio de compensação, o Brasil adquiriu de Roma três submarinos, da classe Perla ${ }^{81}$ Para fechar o negócio, o governo italiano concordou que o valor fosse pago em $60 \%$ de algodão e $40 \%$ em outros produtos agrícolas. ${ }^{82}$

Com a renovação material parcialmente em execução, a Marinha passou a agir para resolver um outro problema: o treinamento de pessoal para operar esses novos navios. Como forma de remediar a situação, o Brasil e os Estados Unidos negociaram a cessão de seis velhos contratorpedeiros, da classe Wickes. ${ }^{83}$

\footnotetext{
${ }^{76}$ MINISTÉRIO DA MARINHA, 1937, op. cit., p. 89.

77 BITTENCOURT, Júlio Regis. Memórias de um Engenheiro Naval. Rio de Janeiro: Serviço de Documentação da Marinha, 2005. P. 172. Alguns autores e documentos brasileiros tendem a identificar essa classe de contratorpedeiros como Cassin (ver VIDIGAL, op. cit., p. 81; MARTINS et al, op. cit., p. 184; MINISTÉRIO DA MARINHA, 1940, op. cit., p. 90). Entretanto, o USS Cassin era um navio da classe Mahan, uma das predecessoras da famosa classe Fletcher. Segundo Scheina (op. cit. P. 327), os navios brasileiros eram variantes da classe Mahan.

78 VIDIGAL, op. cit., p. 81.

${ }^{79}$ MINISTÉRIO DA MARINHA, 1940, op. cit., p. 21.

${ }^{80}$ McCANN, 1995, op. cit., p. 151.

${ }^{81}$ MINISTÉRIO DA MARINHA, 1937, op. cit., p. 90.

${ }^{82}$ HILTON, 1977b, op. cit., p. 70.

${ }^{83}$ Os seis contratorpedeiros eram: Tarbell, Yarnall, Upshur, Greer, Brackinridge e Brakeley. MINISTÉRIO DA MARINHA, 1942, op. cit., p. 312.
} 
A negociação dos navios, construídos entre 1918 e $1920,{ }^{84}$ foi discutida entre o embaixador brasileiro nos Estados Unidos, Oswaldo Aranha e Roosevelt, ganhando rapidamente a aprovação do Senado, do Departamento de Estado e do Departamento de Marinha. ${ }^{85}$ As negociações eram secretas, para evitar complicações perante os setores isolacionistas estadunidenses e contornar os obstáculos dos acordos internacionais de limitação naval. ${ }^{86}$

Quando os detalhes do acordo já estavam praticamente acertados, a notícia veio à tona na imprensa em agosto de 1937. Imediatamente à divulgação, ocorreram vários protestos nos Estados Unidos e no exterior contra o acordo. A U.S. Naval League protestou contra o que considerava uma redução no poder naval estadunidense; grupos pacifistas, no Congresso e na sociedade civil, vocalizaram a oposição ao acordo afirmando que tal transferência incentivaria uma corrida armamentista naval na América do Sul, preocupação também exposta pelo New York Times. A Grã-Bretanha também se mostrou contrária ao acordo, oficialmente afirmando que ele feria o Tratado Naval de Londres (sucessor do Tratado Naval de Washington), mas também preocupando-se que tal medida afetasse as vendas de navios de guerra britânicos para a região. ${ }^{87}$

Os maiores protestos vieram da Argentina. O país considerava que o arrendamento dos navios era uma perigosa interferência estadunidense no equilíbrio naval sul-americano. O ministro das relações exteriores, Carlos Saavedra Lamas, afirmou que tal ato iria "desencadear uma corrida armamentista na América Latina e a destruição do pan-americanismo" ${ }^{88}$ Diante da grande pressão interna como dos dois países citados, os Estados Unidos decidiram recuar, para espanto dos brasileiros. A veemência dos protestos argentinos fizera as tensões entre os dois países aumentarem e, por algum tempo, as lideranças brasileiras passaram a considerar uma guerra com a Argentina como possível. A preocupação foi suficiente para que o Exército e Marinha fizessem, discretamente, levantamentos sobre suas capacidades defensivas nas fronteiras Sul e Oeste do país contra uma eventual invasão argentina. ${ }^{89}$

\footnotetext{
${ }^{84}$ VIDIGAL, op. cit., p. 80. Alguns destes navios seriam cedidos, posteriormente, à GrãBretanha por ocasião da cessão de contratorpedeiros por bases militares no hemisfério ocidental em 1940.

${ }^{85}$ SCHEINA, op. cit., p. 137.

${ }^{86}$ SEITENFUS, op. cit., p. 57.

${ }^{87}$ SCHEINA, op. cit., p. 137.

${ }^{88}$ SEITENFUS, op. cit., p. 57.

${ }^{89}$ HILTON, 1977b, op. cit., p. 80.
} 
A decisão estadunidense em relação aos contratorpedeiros abalou a cúpula militar e civil do governo Vargas, fragilizando a confiança deles na sinceridade das declarações dos Estados Unidos. ${ }^{90}$ A decepção dos militares brasileiros era particularmente maior, o que incitou-os a buscar parceiros mais comprometidos com a modernização das Forças Armadas, mesmo que se encontrassem em Roma ou Berlim. ${ }^{91} \mathrm{O}$ empenho pessoal de Mussolini em garantir a chegada dos submarinos encomendados pelo Brasil em 1938, batizados de classe Tupy aqui, certamente contribuiu para essa visão. ${ }^{92}$

\section{O Estado Novo e o alinhamento brasileiro}

Pouco tempo após o fracasso das negociações para a transferência dos contratorpedeiros estadunidenses, a crise política brasileira se agravou, culminando num golpe de Estado em novembro que implantou o Estado Novo. O novo regime ditatorial representou o ápice da aliança de Vargas com os militares, num momento em que houve uma coincidência de interesses quase total entre presidente e corporação militar. ${ }^{93}$ Como tal, as prioridades da política externa tornarem-se duas: equipamentos para as Forças Armadas e a siderurgia nacional.

A Marinha teve uma participação pequena no planejamento do golpe que deu início ao Estado Novo. Quando os generais Dutra e Góes Monteiro procuraram o ministro da Marinha, Henrique Aristides Guilhem, ele respondeu que "tal como em 1889 e 1930" a Marinha estava ao lado do Exército. ${ }^{94} \mathrm{O}$ almirante Américo Mello, em suas memórias, contou que poucos dias antes do golpe os almirantes foram reunidos para um encontro com os ministros da Marinha e da Justiça. Na reunião, apesar de serem sondados sobre a conjuntura política, saíram sem saber a razão do encontro ou o que ocorreria. ${ }^{5}$ Como afirma McCann, a Marinha não podia fazer muito além de declarar solidariedade aos generais, uma vez que ela já "não era um centro de decisões". ${ }^{96}$

Os integralistas, de outro lado, tiveram uma atuação bem mais importante para a execução do golpe de Estado. Vargas buscou fazer uma aliança com a AIB, sinalizando a Salgado que, caso aderisse, receberia a

\footnotetext{
${ }^{90}$ McCANN, 1995, op. cit., p. 44.

${ }^{91}$ SEITENFUS, op. cit., p. 58.

92 VIDIGAL, op. cit., p. 81.

${ }^{93}$ CARVALHO, op. cit., p. 102.

${ }^{94}$ McCANN, op. cit., p. 43-44.

${ }^{95}$ MELLO, op. cit., p. 129.

${ }^{96}$ McCANN, 1995, op. cit. P. 44.
} 
pasta da Educação. ${ }^{97}$ Os integralistas apoiaram entusiasmados o golpe em novembro, mas a aliança teria curta duração. Cerca de um mês depois do início do Estado Novo, Vargas assinou um decreto proibindo atividades partidárias no país. ${ }^{98} \mathrm{O}$ decreto atingiu em cheio a AIB e ao final de dezembro a polícia reprimiu duramente o partido, fechando centros, jornais e sedes da AIB, além de fazer semanalmente inúmeras prisões contra integrantes do movimento. ${ }^{99}$

A resposta dos integralistas iria ser em breve e uma série de acontecimentos e rumores indicavam a complacência da Marinha com as ações da AIB. Quando os submarinos adquiridos na Itália chegaram a Recife, a caminho da capital, um grupo de integralistas fez sua conhecida saudação, então proibida, aos três navios, ao que as tripulações responderam. $\mathrm{O}$ incidente irritou Vargas, que declarou que não autorizaria as promoções programadas dos oficiais submarinistas. Diante disso, alguns almirantes e o ministro Guilhem ameaçaram se demitir. E numa noite, em meio ao carnaval, enquanto Vargas ponderava sobre a questão, vários navios da esquadra ancorados no Rio de Janeiro subitamente puseram seus motores em movimento. $\mathrm{O}$ recado foi recebido por Vargas, que aprovou as promoções. ${ }^{100} \mathrm{~A}$ chegada dos submarinos à capital suscitou novos rumores. Dizia-se que integralistas guarneciam os navios e quando Vargas fosse visitá-los, seria capturado e levado em alto mar para ser deposto. O presidente não deu atenção aos rumores e sua visita aos navios não teve nenhum incidente. ${ }^{101}$

Em maio de 1938 os integralistas atacaram o regime, iniciando um putsch para derrubar o presidente. $\mathrm{O}$ levante demonstrou a grande presença de elementos da Marinha neste movimento: a principal ação, a invasão do Palácio de Guanabara, que visava assassinar Vargas, foi comandada por um oficial dos Fuzileiros Navais. Houve também a rebeliões menores de pessoal naval no Ministério da Marinha, na Escola Naval, no cruzador Bahia e na estação de rádio na Ilha do Governador. ${ }^{102}$

Com a derrota dos integralistas, cerca de 1600 pessoas foram colocadas em custódia, das quais um terço eram integrantes das Forças Armadas, principalmente da Marinha. ${ }^{103}$ Por esta razão, não se espanta que

\footnotetext{
${ }^{97}$ HILTON, 1977b, op. cit., p.48.

${ }^{98}$ SEITENFUS, op. cit., p. 79.

${ }^{99}$ McCANN, 1995, op. cit., p. 75.

${ }^{100}$ Ibid., p. 75.

${ }^{101}$ BITTENCOURT, op. cit., p. 178.

102 MARTINS et al, op. cit., p. 141-143.

${ }^{103}$ McCANN, 1995, op. cit., p. 82.
} 
grande número de expurgos ocorreu nesta instituição posteriormente ao episódio. ${ }^{104}$

Apesar da derrota da linha integralista da Marinha, Vargas continuou preocupado com a lealdade naval ao seu governo. Manteve a execução do programa naval, mas cortou o orçamento da Marinha ${ }^{105}$ e a manteve em rédeas curtas em relação ao combustível e munição até 1942, como forma de amenizar uma possível ameaça ao seu governo. ${ }^{106}$

Esse episódio terminou com a eliminação de uma tendência bem organizada dentro da Marinha, que afetava a organização hierárquica profissional ao criar lealdades partidárias. Com isso, em termos de política interna a maior ameaça ao governo Vargas desaparecia, enquanto em termos de política externa a eliminação da corrente integralista afetava bastante a linha mais pró-Eixo dentro da força naval. Mas o enfraquecimento dessa linha não significava que a Marinha voltava-se automaticamente para uma posição pró-Estados Unidos. Era preciso resolver a questão prática dos armamentos.

Dando prosseguimento ao programa naval, a Marinha iniciou a construção de seis navios mineiros no Arsenal da Ilha das Cobras. O material necessário para a construção destas embarcações, classe Carioca, foi adquirido na Grã-Bretanha. ${ }^{107}$ Neste mesmo país foram encomendados seis contratorpedeiros, da classe $H$, nomeados Javary pela Marinha. ${ }^{108}$ Os planos naquele momento incluíam a posterior construção de mais seis contratorpedeiros Javary e outros seis navios mineiros classe Carioca no Brasil, além de adquirir outros três submarinos da Itália e ao menos dois cruzadores na Grã-Bretanha. ${ }^{109}$ Este planejamento indica um claro afastamento da influência estadunidense, certamente fruto das dificuldades em se adquirir armamentos naquele país bem como do recente desapontamento em relação à crise dos contratorpedeiros.

Entretanto, o rápido desenrolar dos eventos e o agravamento da crise europeia, que culminaria no início da Segunda Guerra Mundial, reaproximariam a Marinha dos Estados Unidos.

Diante dos atrasos nos pagamentos dos contratorpedeiros Javary, a produção destes navios acabou se arrastando, cuja finalização ocorreu apenas no segundo semestre de 1939. Com a eclosão da guerra e por virtude

\footnotetext{
${ }^{104}$ MARTINS et al, op. cit., p. 143.

${ }^{105}$ CARVALHO, op. cit., p. 89.

106 US DEPARTMENT OF STATE, op. cit., p. 65.

${ }^{107}$ MINISTÉRIO DA MARINHA, 1940, op. cit., p. 86.

108 SCHEINA, op. cit., p. 327.

${ }^{109}$ MINISTÉRIO DA MARINHA, 1940, op. cit., p. 22.
} 
de uma cláusula no contrato, os navios acabaram requisitados pelo governo britânico. ${ }^{110}$ Outro agravante foi que com o início da guerra encerraram-se as negociações de compra de novas embarcações em estaleiros europeus. A partir de então, o único país em que a Marinha efetivamente poderia comprar navios e materiais para a construção naval eram os Estados Unidos.

O início da guerra na Europa também teve a consequência importante de oferecer ao presidente Roosevelt uma flexibilidade maior em relação aos rígidos controles da política isolacionista estadunidense. A nova política, apelidada de cash and carry, permitia que qualquer país beligerante pudesse comprar armas estadunidenses, desde que pagasse à vista e levasse em navios próprios ou de neutros. ${ }^{111}$

Apesar dessa novidade, pouco mudava em relação à questão dos armamentos para o Brasil, uma vez que não tinha capacidade de adquirir material bélico pagando segundo os modelos liberais do comércio internacional. Tudo isso ocorria num momento que o país ganhava ainda mais importância estratégica para os Estados Unidos, ${ }^{112}$ o que implicava que estadunidenses teriam que buscar outras linhas de ação.

Diante do fechamento do mercado europeu e das dificuldades em obter navios de guerra nos Estados Unidos, a Marinha voltou-se novamente para a construção naval no Brasil. A requisição dos Javary pela GrãBretanha obrigou aos líderes navais brasileiros iniciar a construção imediata de seis novos contratorpedeiros no país, da classe Amazonas, usando os projetos dos navios requisitados. ${ }^{113}$

A Missão Naval Americana teve uma atuação decisiva para a produção destes navios. Através dela, os estadunidenses adaptaram os

110 VIDIGAL, op. cit., p. 81.

111 ALVES, 2002, op. cit., p. 83-84.

112 Com o desfecho da crise de Munique, em setembro de 1938, o governo Roosevelt deu início à uma nova política de defesa nacional, baseada na defesa hemisférica de todo o continente americano contra agressões externas. Dentro desta perspectiva, o saliente Nordestino brasileiro tinha grande importância estratégica: era o ponto mais oriental da América e suas condições climáticas/geográficas o tornavam um ponto excelente de trânsito aéreo entre o Velho Mundo e o Novo Mundo. Além disso, o arquipélago de Fernando de Noronha, distante algumas centenas de quilômetros da costa brasileira, oferecia uma excelente base para controle de tráfego intercontinental. Caso tal região fosse ocupada por uma potência hostil, poderiam usar aviões baseados nesse local para atacar o Sul dos Estados Unidos ou o vital Canal do Panamá. Assim, era fundamental para o planejamento estadunidense a defesa dessa região, especialmente após a queda da França, uma vez que isso possibilitaria aos alemães usar os territórios da África Ocidental Francesa para lançar ataques contra o continente americano (ALVES, op. cit., p. 91-94). Para ver mais sobre os planos de defesa hemisférica, ver CONN, Stetson \& FAIRCHILD, Byron. Estrutura de Defesa do Hemisfério Ocidental. Rio de Janeiro: Biblioteca do Exército, 2000.

${ }^{113}$ MINISTÉRIO DA MARINHA, 1940, op. cit., p. 87. 
planos britânicos para a fabricação com material proveniente dos Estados Unidos. ${ }^{114}$ Diante do sucesso em iniciar a construção de mais seis contratorpedeiros, a Marinha passou a considerar iniciar a fabricação de submarinos. Inicialmente, existia uma proposta holandesa para a fabricação desses navios no Brasil, mas o acordo não avançou. Pensou-se em utilizar os planos do Tupy, porém o país acabou-se voltando para os Estados Unidos para buscar os planos e materiais para a fabricação dos submarinos. ${ }^{115}$

$\mathrm{O}$ apoio dos Estados Unidos à construção naval no Brasil cumpria alguns interesses. Ao auxiliar a Marinha a conseguir seus necessários armamentos produzindo-os no Rio de Janeiro, não comprometia sua produção bélica para outras necessidades além do rearmamento das forças militares estadunidenses. Da mesma maneira, não exigia o pagamento imediato, já que o Brasil tinha dificuldades em realiza-lo em moeda forte segundo as normas liberais do comércio internacional. ${ }^{116}$

É preciso também ressaltar que o apoio dado para a Marinha decorria da postura majoritariamente pró-Estados Unidos, que inspirava mais confiança do que o Exército. Essa nova visão era resultado da construção de um consenso interno na Marinha, finalizada com os expurgos pós-putsch integralista.

Assim, principalmente por meio da Missão Naval Americana e pelo apoio à construção naval, a Marinha assumiu uma posição majoritariamente pró-Estados Unidos nos difíceis momentos em que os Aliados passavam no ano de 1940. Mesmo a proposta italiana, naquele mesmo ano, de oferecer seis submarinos semelhantes ao Tupy - metade dos quais seriam entregues imediatamente $^{117}$ - não mudou a postura pró-Aliados da força naval brasileira.

Apesar da postura da Marinha, o alinhamento brasileiro ainda dependeria da resolução da questão da siderurgia e dos armamentos para as Forças Armadas. Como se sabe, a demanda da siderurgia seria rapidamente resolvida após a queda da França, em junho de 1940. Já a questão dos armamentos demoraria mais tempo. Entretanto, o apoio à renovação da Marinha garantia uma posição mais favorável aos Estados Unidos nesse importante segmento militar.

Com a desenvoltura da guerra, os Estados Unidos tomaram cada vez mais ações buscando ajudar a causa Aliada. Em março de 1941, Roosevelt conseguiu aprovar o lend-lease, que significou o fim de qualquer restrição

\footnotetext{
114 VIDIGAL, op. cit., p. 81.

115 MINISTÉRIO DA MARINHA, op. cit., p. 23-24.

116 WALDMANN JÚNIOR, op. cit., p. 79-80.

${ }^{117}$ McCANN, 1995, op. cit., p. 151.
} 
legal para o auxílio material norte-americana para quaisquer países aliados e transformou os Estados Unidos no "arsenal das democracias". 118

Alguns meses depois o país era atacado pelo Japão e entrou diretamente no conflito global. A entrada dos Estados Unidos na guerra teve profundas consequências para os países americanos. A Conferência do Rio de Janeiro, em janeiro de 1942, formalizou o rompimento de relações entre as repúblicas americanas (com exceção da Argentina e Chile) com o Eixo e o alinhamento brasileiro aos Estados Unidos. ${ }^{119}$

Com o alinhamento brasileiro, o país passou a receber recursos do lend-lease a partir de fevereiro/março de $1942 .{ }^{120}$ No caso específico da Marinha, receberia novos navios apenas a partir de setembro daquele ano, com os dois caça-submarinos da classe Guaporé. No total, a Marinha acabaria recebendo, via lend-lease, vinte e quatro novos navios, sendo dezesseis caça-submarinos e oito contratorpedeiros de escolta. ${ }^{121}$

A boa relação entre a Marinha e os Estados Unidos também possibilitou a colaboração militar fosse estabelecida mais rapidamente que entre os exércitos dois países. ${ }^{122}$ Como aponta Oliveira, desde meados de 1941 a US Navy tinha autorização de Vargas e cooperação de autoridades navais e locais para utilizar portos no Nordeste brasileiro como bases navais, como também desenvolvia a infraestrutura naval necessária para sua utilização no conflito. De outro lado, o exército estadunidense teve enorme relutância em apoiar o desenvolvimento militar brasileiro. ${ }^{123}$ Mesmo em 1943, com o Brasil já na guerra, existia entre os militares dos Estados Unidos preocupações em relação à lealdade de alguns oficiais do Exército brasileiro à causa aliada. ${ }^{124}$

\section{Considerações finais}

O alinhamento brasileiro aos Estados Unidos na Segunda Guerra Mundial foi um processo longo, iniciado a partir da contenda entre Estados Unidos e Alemanha pelo comércio exterior do Brasil em meados da década de 1930. Nesta disputa, a questão da siderurgia e do fornecimento de armamentos era central e o atendimento dessas demandas decidiria o posicionamento brasileiro.

\footnotetext{
118 ALVES, 2002, op. cit., p. 116-117.

119 Ibid., p. 118-119.

120 Ibid., p. 132.

${ }^{121}$ SCHEINA, op. cit., p. 328-329.

122 DAVIS, op. cit., p. 35-36.

123 OLIVEIRA, op. cit., p. 50-51.

${ }^{124}$ Ibid., op. cit., p. 62.
} 
De maneira semelhante, é preciso dar atenção para a dinâmica política interna do Brasil, onde setores pró-Aliados e pró-Eixo disputavam a imposição de suas demandas para o posicionamento brasileiro no cenário internacional. Nesse quadro, como demonstramos, a Marinha vai assumir uma posição decisivamente pró-Estados Unidos, especialmente a partir de 1939.

Esse posicionamento foi resultado de uma forte influência dos Estados Unidos dentro da Marinha. Essa influência dava-se mais por razões práticas do que por ideológicas. Desde a chegada da Missão Naval Americana, em 1922, a maioria da oficialidade naval via os Estados Unidos como um parceiro importante, que auxiliava a Marinha a se modernizar, seja em termos organizacionais, em treinamento e por fim, materialmente. O apoio estadunidense à construção naval no Brasil, tema caro à Marinha, certamente fortalecia a imagem dessa parceria.

Há de se ressaltar também a importância da construção de um consenso interno na Marinha favorável aos Estados Unidos. Aqui, destacase a importância da derrota do integralismo, que tinha grande apoio entre o pessoal naval. A queda do integralismo vai eliminar uma perigosa tendência pró-Eixo, reforçando a hierarquia profissional e a linha que via os Estados Unidos como um parceiro.

É importante apontar que a posição pró-Estados Unidos da Marinha não vai implicar, automaticamente, uma posição semelhante na política externa brasileira. A Marinha tinha uma posição secundária em importância política no Estado Novo e, portanto, não conseguiria sozinha impor suas pautas ao governo Vargas. De outro lado, o Exército assumia um protagonismo importantíssimo, cuja demanda por armamentos foi fundamental para o entendimento das negociações que levaram ao alinhamento brasileiro.

Neste sentido, podemos ver importantes diferenças entre a Marinha e o Exército. Enquanto a Marinha era mais aberta à aliança com os Estados Unidos, o Exército assumiu uma posição mais receosa, exigindo os armamentos prometidos antes de qualquer tomada de posição mais definitiva. No caso da Marinha, a colaboração estadunidense com o rearmamento dessa força é anterior, tendo em vista o apoio da Missão Naval Americana para a produção de navios de guerra no Brasil.

Por fim, cabe ressaltar que a proximidade cultivada entre a Marinha e os Estados Unidos daria importantes resultados em termos de cooperação militar. A US Navy e a Marinha já estavam colaborando nos planos de defesa hemisférica antes mesmo da entrada do Brasil na Segunda Guerra Mundial. Essa aproximação teria resultados de longo prazo e as duas 
marinhas mantiveram colaboração que durou por décadas após a derrota final do Eixo.

Recebido em Setembro de 2015.

Aprovado em outubro de 2015. 